\title{
流動海水中における銅合金の分極についで
}

\section{On the Polarization of Copper Alloys in the Running Sea Water}

\author{
佐 熊 純 一** \\ Junichi $S_{\text {AKuMA }}$
}

\section{1. 緒言}

耐海水用として使用される銅合金材料は流動海水また はキャビテーション中で使用されるここが多く，そのた めに窝食を発生するととる多い。このような場合の窝食 性汅よび防食性について知るためには流動状蟹下におけ るそれら材料の分極特性を知るととが必要であるが，と れについてまとまった筫料が比較的すくないい,2\}。本武 験では主として舶用によく使用される銅合金として錫青 銅，マンガン黄銅を選び，回流装置によって流動海水中 の分極試験を行なった。

\section{2. 試 験 装}

武験は図 1 亿示すような小型回流装置を用いて行なっ た。試験片取付部の詳細は図 2 亿示す。ての種の武験装 直としては，試験ソウ中で円筒形の試験片を回転させる 方式 (3),4),5) らが多く使用されているがキャビテーション 老発生させる必要のあること，および試験片面の变化， 流動状況を観察する必要上，本試験では試験片を静止し て水を流動させる方式をとった。したがって武験片取付 部は透明樹脂を使用して内部の観察を容易にし，またキ ヤビテーション発生用の障害を試験片の上流に設けた。

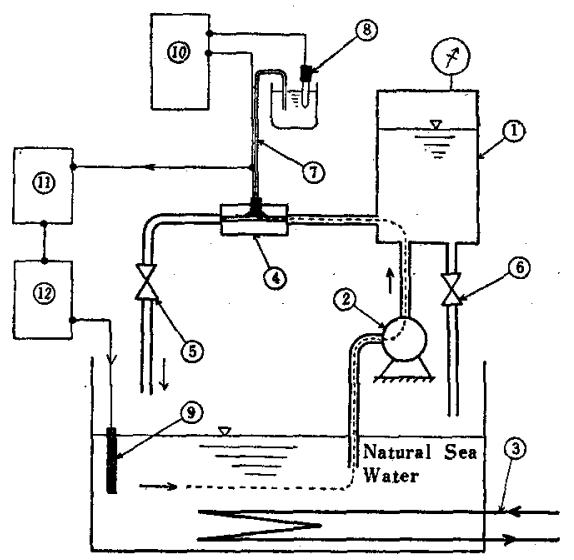

図 1 回流装置略図

(1) サージタンク (2) 回流用ポンプ (3) 冾却水 (4) 試踰片取付

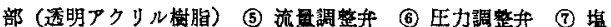

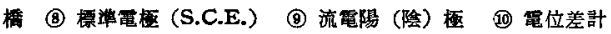
(11) 電梳計 等 電梳娚整器

- 昭和 35 年 10 月 29 日 電気化学協会第 6 回碳食防討論会（神戸 市)にて器表

*掅磨造船所（兵康県相生市相生）

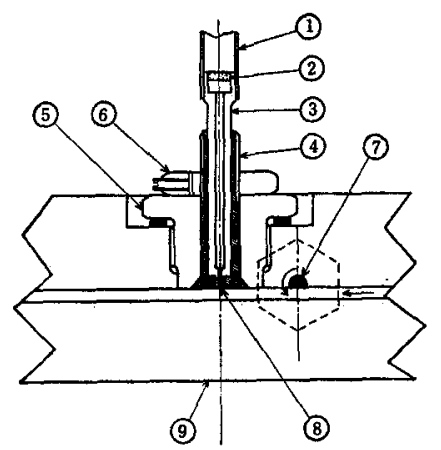

図2 試験片取付部詳紐

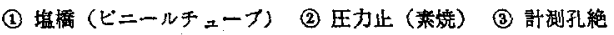

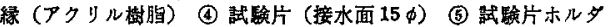
一(フクリル樹脂) (8) ナット (7) キャビテーンョン発生用突起 (8) 電位計椡孔 $0.6 \phi$ (9) 試駼片取付部本体（透明アクリ几樹脂） 発生機構は図1に示す.分極電位の計測法としては特に 高電流密度における IR ドロップをさけるために図 20 ように試験片の中央から小孔によって塩橋をとり小孔内 壁は完全に絶縁しているが，なお間接法電位測定により 電流切断後 $1 / 1,000$ 秒程度の電位計測を行なって IR ド ロップの影響のないととを確認した，海水中の溶存酸素 量は Winkler の方法により数回計測したが，ほとんど 飽和状態と考えてよい。

供武材料の成分は表 1 亿示す.

表 1 供試材料の成分

\begin{tabular}{|c|c|c|c|c|c|c|c|c|c|}
\hline \multirow{2}{*}{ 材 (JIS) } & \multicolumn{3}{|r|}{ 成 } & \multicolumn{2}{|c|}{ 分 } & \multicolumn{3}{|l|}{$(\%)$} & \multirow{2}{*}{ 熱処理組䋨 } \\
\hline & $\mathrm{Cu}$ & $\mathbf{Z} \mathbf{n}$ & Sn & $\mathrm{Fe}$ & $\mathrm{Ni}$ & $\mathrm{Pb}$ & Al & Mn & \\
\hline (BC 2$)^{\text {銅 }}$ & 88.87 & 3.49 & $7.06 \mid$ & 0.01 & 0.51 & $|0.03|$ & -1 & & 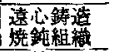 \\
\hline 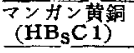 & 56.85 & 37.67 & -1 & 0.69 & -1 & -1 & 0.42 & 4.37 & 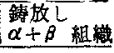 \\
\hline
\end{tabular}

\section{3. 低電流密度における分極}

\section{1 腐食電流密度 $i_{\text {corr }}$}

低電流密度における分極㘽験は主として $i_{\text {corr. }}$ か海水 ○流動状熊によって，变化する模様を知るために行なっ た。したがって低電流密度の範囲については最高 $5 \mathrm{~A} / \mathrm{m}^{2}$ 程度以下を対象として, それ以上は高電流密度とよぶこ とにした。

$i_{\text {corr. }}$ の求め方についてはStern ら ${ }^{6), 7)}$ と類似の考元 方によって供武電極に流した 外部電流密度 $i_{\text {ext. }}$ とその

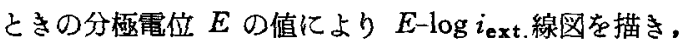




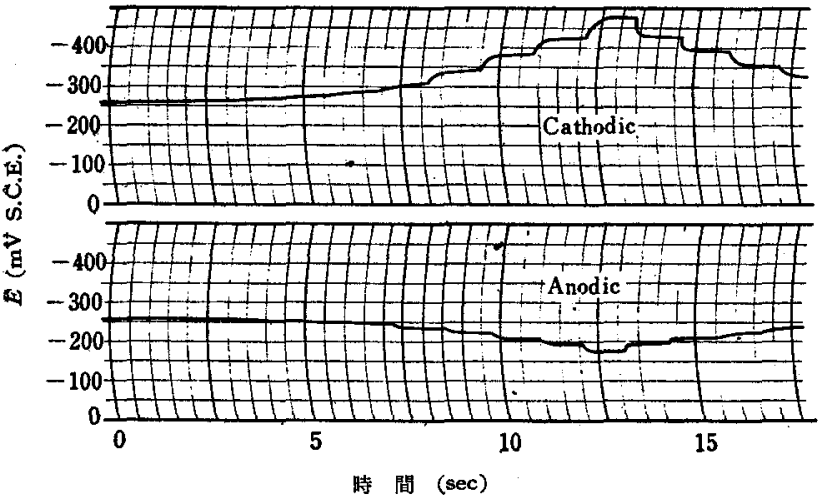

図 3 迅速分極試験汇上る電位記録結果の一例

直流增㠷・ベンオンロによる。材料, 鋁青銅, 研摩直後, 自然海水 $\left(20^{\circ} \mathrm{C}\right)$

$i_{\text {ext }}$ 線図上で $(R T / n F) \ln k$ に相当するだけ平 行にずれるととになる．以上は陽分極関する ものであったが，陰分極についても $\mathrm{O}_{2}$ などの 被還元種について類似のととが考えられ た合金についても，同樣のてとがい元るから，て れら陰陽両分極のTafel 線によ。て求められる i corr は流速が上がることにより大きくなるは ずである.

実験の結果は図4のようになり，たとえば流 速が $0.1 \mathrm{~m} / \mathrm{sec}$ から $10 \mathrm{~m} / \mathrm{sec}$ になると $i_{\text {corr }}$ は約 3 倍程度に增大している。乙の図の実線は 研摩直後の場合であるが, マンガン黄銅の $i_{\text {corr }}$ が錫青銅の場合上りかなり大る出ていて窝食 しやすいように思われる。しかしてのような表 その陰陽両分極線の Tafel 線部の延舆によって生ずる交

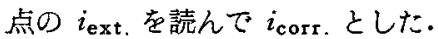

\section{2 実験方法}

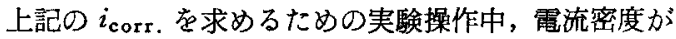
上がると電極表面の状態が自然笍食時の状態と変ること がいわれているので8 本武験においても迅速分極試験法 によって行なった。この方式は回路の途中に抵抗切換接 点を設けて電流密度の迅速切换を行ない分極電位の変化 をオシログラフにとるるのであるが，図 3 に示すように charge up 曲線の電位変化の遅れが 2 秒前後までは大き いので，これがある程度定常化した值をとった。

\section{3 実験結果およひ検封}

いま，陽分極について考光ると電極表面の流速が異 なるこにによって電極の溶解イオン拡散屏の厚さ $\delta$ は 湾化するから，その内外におけるイオン濃度差ば”,

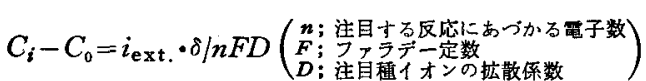

外部電流密度 $i_{\text {ext. }}$ がー定であれば活性化過電圧の変

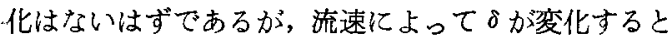
(1) 式によって表面のイオン濃度 $C_{i}$ の変化が生ずる ために，てれに対応する溶解電位 $E_{C_{i}}$ の変化がある と $E_{1}$ t $i_{\text {ext }}=i_{1}$, 注目イオンの活量 1 のときの $E_{C_{i}}$ の值とすると，

$$
E_{C_{i}}=E_{1}-(R T / n F) \ln C_{i}
$$

ただし溶液は注目イオンについて希幥であり $a_{i} \cong C_{i}$, また $C_{0} \cong 0$ とする． $a_{i}$ は活量.

(1) 式を（2）沉れて,

$$
E_{C_{i}}=E_{1}-(\mathrm{RT} / n F) \ln \left(i_{\mathrm{ext}} \cdot \delta / n F D\right)
$$

いま流速の変化によって $\delta \rightarrow k \delta$ になったとする $(k$ 《定数)

$$
\begin{gathered}
E_{C_{i}=E_{1}-}(R T / n F) \ln \left(i_{\text {ext }} \cdot \delta / n F D\right) \\
-(R T / n F) \ln k
\end{gathered}
$$

したがって (4) 式であらわされる Tafel 線は $E_{C_{i}}-\log$

面状沉は，キャビテーション中または土砂を含む水の場 合に適用されるべきものであって，普通の流水中におい ては表面被膜による影響か加わるから，てれと異なった 分極を示す．図 4 中に点線で示す分極線は $15 \sim 20^{\circ} \mathrm{C}, 10$ $\mathrm{m} / \mathrm{sec}$ の流動海水中に 20 時間放置したのちのるので, これによるとマンガン黄銅の $i_{\text {corr }}$ は非常に減少してい るのに反し，錫青銅の場合は増加している。ての增加す る原因は 20 時間浸せき後，表面を顕微鏡で観察すると すでに食の進行が認められるので分極試験における実 貿的な電流密度が減少している結果と思われる．マンガ ン黄銅に扑ても浸せき後はかなり窝食を生じている
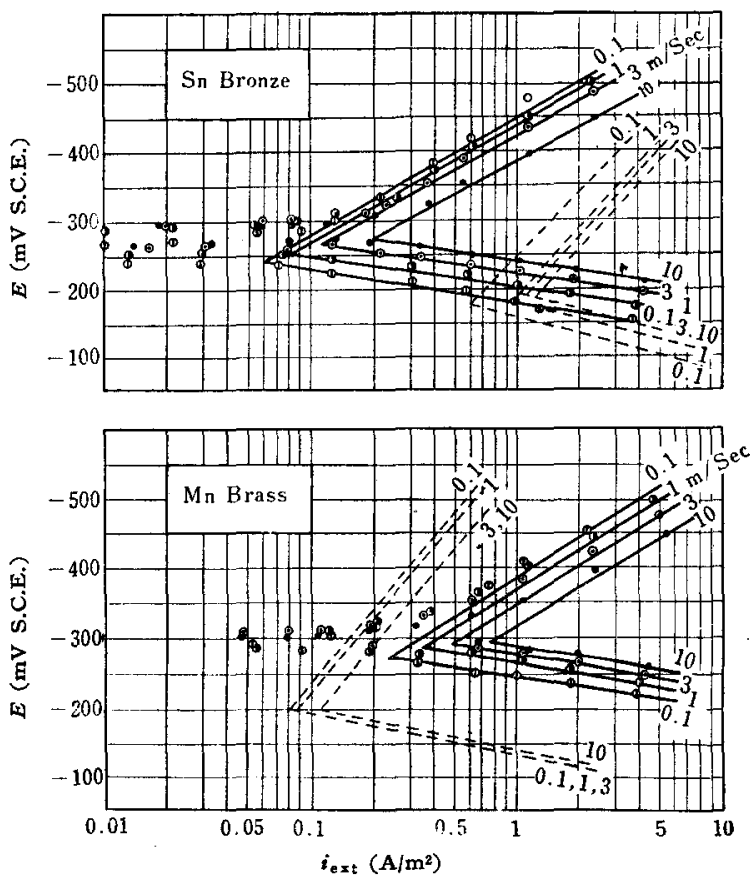

図 4 分極線による荫食電流決定の一例

自然海水 $\left(20^{\circ} \mathrm{C}\right)$

实線は研摩直後の場合 点線は研摩啳 20 時間流野海水中に浸せせの場合 

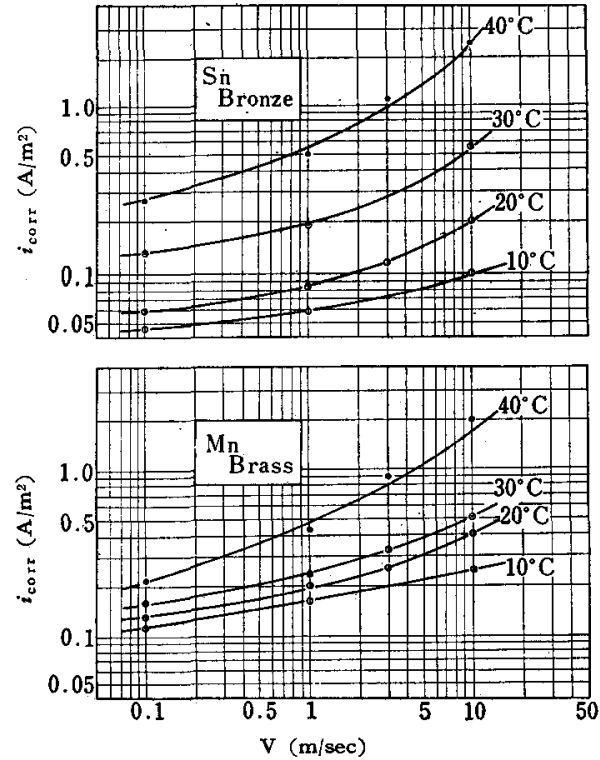

図 5 海水温度，流速 $(V)$ による腐食電流 $\left(i_{\mathrm{cor} r}\right)$ の変化 自然海水中, 研摩直後の場合

が，この場合は表面被膜の影響が，さらに罀く現われる ために $i_{\text {corr. }}$ の城少をきたすものと考元られる。

つぎに $i_{\text {corr. }}$ 、は愠度が大きい影響をおよぼす。图 5 は流速と $i_{\text {corr }}$ の関係を $10 \sim 40^{\circ} \mathrm{C}$ の各温度についてあ らわしたものであるが，とくに流速の速い場合における 温度の影響は重要である. 材料的には錫青銅の方が,や やその影響は大きいが，乙の材料はたとえば舶用推進器 軸の接水部被金として常用され $40^{\circ} \mathrm{C}$ 以上の悪条件も十 分ありうることであるから，その部の海水温度を下げる ととは防食および摩籷対策上重要な事項であらう。

\section{4. 高電流密度における分極}

\section{1 試験方法および結果}

低電流密度における分極試験の 目的は $i_{\text {corr }}$ 在求めることにあっ たため迅速分極試駼法によって行 なったが，ここにのべる比較的高 電流密度にわける分極試験は防食 電流による陰極分極を知るととが 主目的であるから分極線の Tafel 線部から水素ガス生成による分極 線部に至る電流密度を対象にし試 跲法も異なる。すなわち第2節に 示した回流装置にわいて試験片に 一定電流密度で通電したまましば らく保持し電位変動が $2 \mathrm{mV} / \mathrm{min}$ 程度に安定するのを待って電位を 読んだが，限界電流密度付近は電
位の変動が激しいので必ずしもそのようにはできなかっ た. 各材料について研摩直後に行なった結果を図 6 亿示 すが，マンガン黄銅を $15 \sim 20^{\circ} \mathrm{C}, 10 \mathrm{~m} / \mathrm{sec}$ の流動自然 海水中に 20 時間浸せきしたのち行なった武験結果は図 7 の実線のようになる。

\section{2 試験結果の検討}

高電流密度にお污る陰極分極線住図6のように主とし て酸素の活性化分極酒よる Tafel 線部, 酸素の拢散遅れ による限界電流部, 水素ガスの生成による分極線などの 部分にわかれているかが吕，海水中にわける銅合金の流電 防食に主として関係するのは限界電流密度 $i_{\mathrm{L}}$ までであ る. 外部電流密度 $i_{\text {ext }}$ と電極電位 $\mathrm{E}$ の関係は Stern ら の式を簡単にして低電流密度の場合も含めてつぎの式 を使用しよう。

$$
\begin{aligned}
E=E_{0} & +\alpha \log \left\{\left(i_{\text {ext }}+i_{m}\right) / i_{\text {corr }}\right\} \\
& \left.+2.3(R T / n F) \log \left\{i_{L}-i_{\text {ext }}\right) / i_{L}\right\}
\end{aligned}
$$

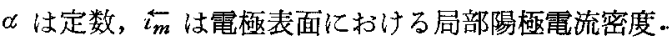
（5）式の第 2 項は酸素の活性化分極を示す項，第 3 項は 限界電流密度付近にわける濃度分極を示す，限界電流密 度澾すると $E$ の值は水素ガスの生成電位 $E_{\mathrm{H}_{2}}$ 亿達す るから $i_{L}$ をこえた場合は

$$
E=E_{H_{2}}+\alpha_{H_{2}} \log \left(i_{\text {ext }} / i_{L}\right)
$$

が分極線をあらわす式としよう． $E_{H_{2}}$ は $i_{\text {ext }}=i_{L}$ なる ときの $E$ の值. $\alpha_{H_{2}}$ は定数. $E_{H_{2}}$ は図 6 で見ると各流 速とも大体 $-1,100 \mathrm{mVS}$.C.E. である.いま $E$ を Volt, $i_{\text {ext }} \mathrm{Amp} / \mathrm{m}^{2}$ であらわすと図6から（5）式の $\alpha$ は $0.17 ，(6)$ 式の $\alpha_{H_{2}}$ は图 8 のように整理すれば 0.83 に なる、以上は電極表面を研摩した直後に行なっだ結果で あるが、マンガン黄銅について流動海水中に 20 時間浸 せき後の結果は，図7のように り 0.6 程度である。 $\alpha_{H_{2}}$ はあまり変化がない

つぎ限界電流密度 $i_{\mathrm{L}}$ と流動状況の関係に対しては 2 重管電極について次式がある"。

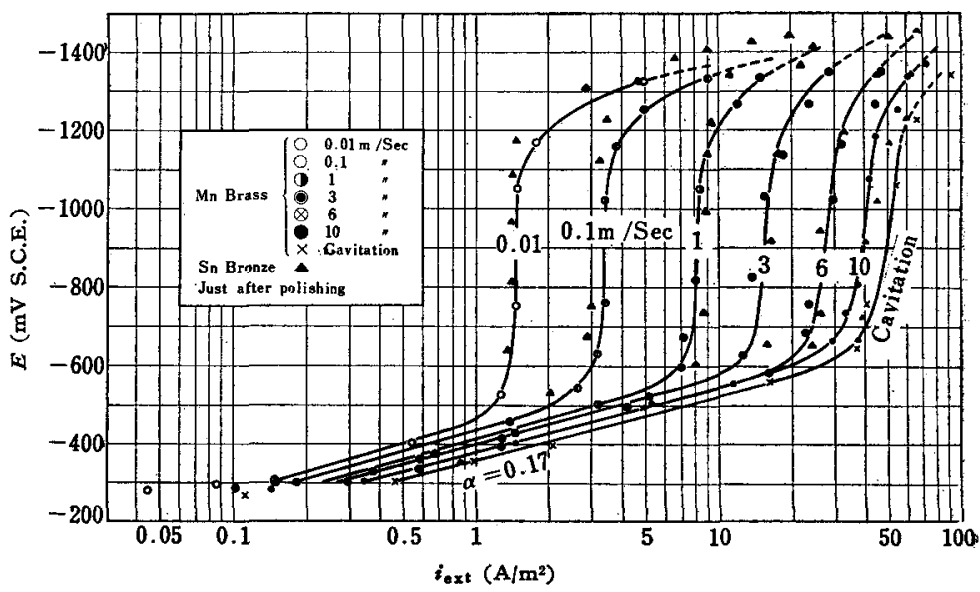

図 6 流速と分極曲線の関係 自然海水 $\left(20^{\circ} \mathrm{C}\right.$, 溶存酸絭能和) 研摩直後の場合 


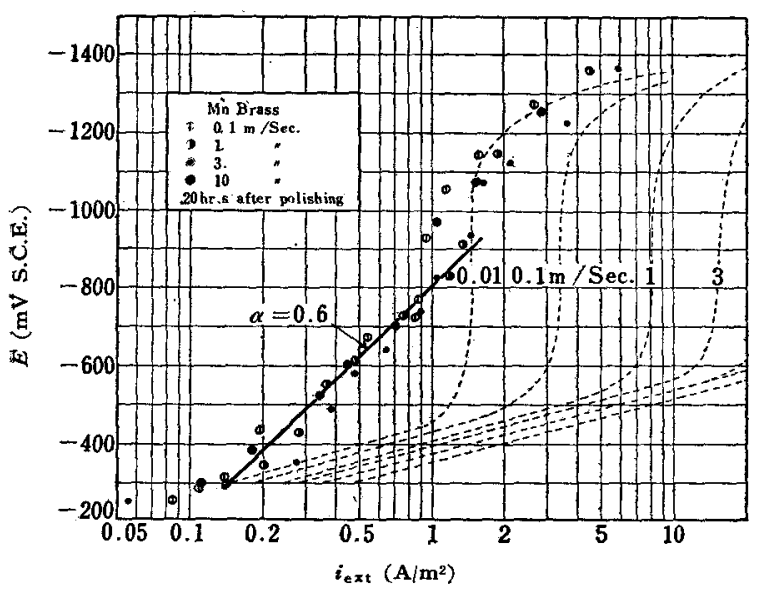

図7 長㭙間浸せきした場合に扔るマンガン黄銅の分極線 浸せき; 20 時間, 自然海水 $\left(15 \sim 20^{\circ} \mathrm{C}, 10 \mathrm{~m} / \mathrm{sec}\right)$

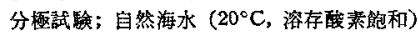

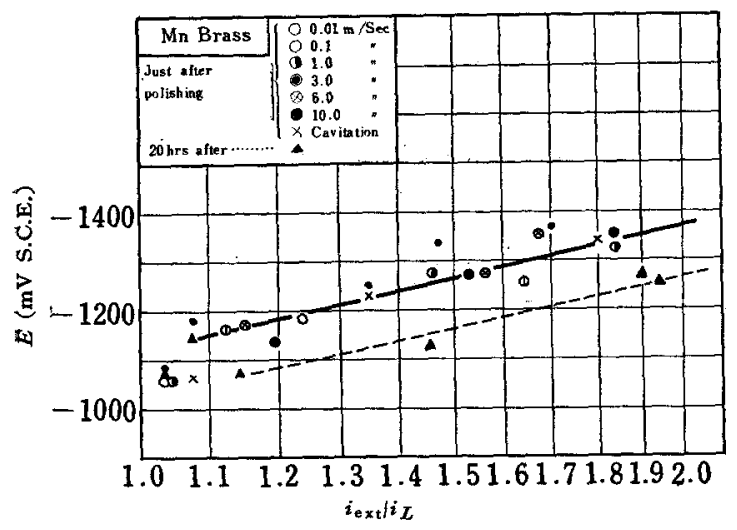

図 8 水素ガス生成電位以上に括汀る電位 $E$ と $i_{\mathrm{ext}} / i_{L}$ の関係 自然海水中 $\left(20^{\circ} \mathrm{C}\right.$, 溶存酸菜蚫和 $)$

実線証摩直後

点楾は 20 時間自然海水 $\left(15 \sim 20^{\circ} \mathrm{C}, 10 \mathrm{~m} / \mathrm{sec}\right)$ に浸世き後

層流の場合 $\mathrm{Nu}=\mathrm{K}_{1} \operatorname{Re}^{\mathrm{m} 1} \mathrm{Sc}^{1 / 3}(d / L)^{1 / 3}$

乱流の場合 $\mathrm{Nu}=\mathrm{K}_{2} \mathrm{Re}^{\mathrm{m} 2} \mathrm{Sc}^{1 / 3}$

ただし $\mathrm{Nu}=i d / n F D C_{0}, \mathrm{~K}_{1}, \mathrm{~K}_{2}$ は定数, $\operatorname{Re}$ はレイノル ズ数で特性長さ $d$ は管径の差, Scはシュミット数, $L$ は 管の镸さ. 本実験の場合は，電極取付部の水路断面は 3 $\mathrm{mm} \times 20 \mathrm{~mm}$ の矩形であるから $\mathrm{d}=0.003 \mathrm{~m}$ とする。 た電極長さ $L$ は短いので，てれによる影響を無視し（7) 式のd/Lの項をはふくと層流，乱流を通じて

$$
\mathrm{Nu}=\mathrm{KRe}^{\mathrm{m}} \mathrm{Sc}^{1 / 3}
$$

となる. Sc の項は溶液固有のものであるから流動状況， 水路の幾何学的形状によってその指数を変える必要はな い. 図9 注摩值後の銅合金に対して $20^{\circ} \mathrm{C}$, 酸素飽利状 態の自然海水中で行なった限界雷流密度試験の絬果を (9) 式によってまとめたものであるが図に示すように乱 流状態と首流状態で異なった直線になり，とれから求め た $k, m$ は図中に示す值になる。

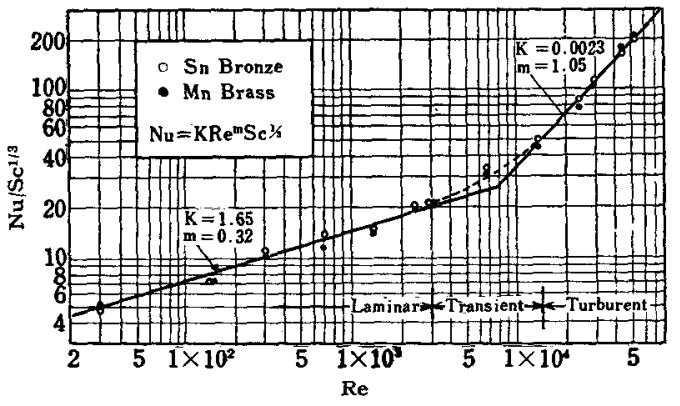

図 9 限界電流と流動状況に関与る線図 自然海水 $\left(20^{\circ} \mathrm{C}\right.$, 溶存酸素澳 7.37 P.P.M., $\mathrm{O}_{2}$ の垃散係数 $1.94 \times 10^{-5} \mathrm{~cm}^{2} / \mathrm{sec}$ )

$\mathrm{Re} ;$ レイノルズ数（特性長さは計測部水路厚さ $\mathbf{3} \mathbf{~ m m}$ )

$\mathrm{Nu}$; ヌッセルト数 Sc;シュミット数

電極研摩後，浸せき時間が長くなると表面被膜の生 成があるため, マンガン黄銅の場合は前述の図7のよ うに各流速における $i_{L}$ の差がほとんど現われない。

\section{5. 結語}

流動海水中において，銅合金の分極試験を行なった結 果，济食電流は表面の流動状況によ。てかなり変化し流 速が上がれい゙昖散層厚さが減少するために增大する・、 ンガン金銅は表面被膜のない状態では非常に窗食電流が 大きいが，被膜の生成によって減少する，錫青銅では浸 せ時間か長くなると実躓表面積か増加するため窝食電 流が増す。また海水温度の影響は大で，いずれも温度の 上舁によ。て霍食電流が增す牲特に高流速の場合は注意 を要する。

高電流密度における陰分極線については電極表面か研 摩直後の状態では上記二つの材料について大体同し絬果 になる.限界電流密度と $\operatorname{Re} の$ 関係は両対数線図上で, 直線になり，それは缯流域と乱流域で異なった㫜線にな る.マンガン黄銅では浸せき時間が長くなると坟面被膜 の影響か河出く現わ机る結果 Tafel 線の傾斜が大になると 同时に限界電流倠か流速に無関係にほぼ一定になる。

終りに本試験の発表に際して討論会にご出序の諸筫よ り種々ご教示を賜わり, 報文作成上の参考にさせていた だいたととを感謝いたす第である。

(炤 35-4-18 受理)

文 献

1) H.B. Bomberger, F.H. Beck, M.G. Fontana, J. Electrochem. Soc. 102, 53 (1955).

2) 重野售太, 小林豊治，本誌 26，599 (1958).

3) 网本 用, 久保田 宏, 本就 22, 56 (1955).

4) M. Eisenberg, C.W. Tobias, C.R. Wilke, J. Electrochem. Soc. 101,306 (1954).

5) C. V. King, J. Electrochem. Soc. 102, 193 (1955).

6) M. Stern, A.L. Geary, J. Electrochem. Soc. 184, 56 (1957).

7) W.J. Schwerdtfeger, O.N. McDorman, J. Electrochem. Soc. 99, 407 (1952).

8）岡本 删，永山政一，佐藤教男，本誌 25，166 (1957).

9) 吉沢四郎, 本誌 25, 584 (1957).

10) E. Schaschl, G.A. Marsh, Corrosion 13, 343 t (1957).

11) G.V. Akimov, Corrosion 14, 463 t (1958). 